\section{Seeing the (En)light}

\section{By Chris Cain, Staff Writer}

AstraZeneca plc and Novo Nordisk A/S have come off the sidelines and joined up with Enlight Biosciences LLC, an entrepreneurial partnership that has established four platform technology companies in less than four years with input from its pharma partners.

Enlight was launched July 2008 with $\$ 39$ million in funding from PureTech Ventures in collaboration with Merck \& Co. Inc., Pfizer Inc. and Eli Lilly and Co.

In addition to the three founding partners, Johnson \& Johnson and Abbott Laboratories joined in 2009, bringing Enlight's total partner count to seven.

CEO Michelle Browner told SciBX that Enlight was founded to address the lack of support for platform technology companies in the VC community.

"Venture capitalists have needed to make sure they can realize high returns from specific therapeutic opportunities. The rationale for creating Enlight, as envisioned by PureTech and senior executives within pharma, was the need to address the decline in creation and investment in technology-focused companies," she said.

Enlight hopes to solve this problem by working with a collective of interested pharma partners to fund new companies developing technology of direct interest to them.

Enlight operates like a venture firm but receives financial support and input from its pharma partners. Thus, investment risk is shared between parties that have a vested interest in developing a given technology for their own use.

Each partner invests an undisclosed amount in Enlight and then can evaluate platform technologies identified by Enlight's network of academics.

"We bring together scientists from across pharmas, determine what the critical needs are in a given focus area and discuss where they see the challenges and the opportunity for transformational change," said Browner.

\section{Table 1. Enlight's offspring.}

\begin{tabular}{lll}
\hline Company & Technology & Founded \\
\hline Endra Inc. & Photoacoustic molecular imaging & 2008 \\
\hline Entrega Inc. & $\begin{array}{l}\text { Formulation technology for oral delivery of } \\
\text { peptides and proteins }\end{array}$ & 2010 \\
\hline Knode Inc. & Web application to identify research experts & 2011 \\
\hline $\begin{array}{l}\text { Ensōf Biosystems } \\
\text { Inc. }\end{array}$ & Systems-level proteomics platform & 2011
\end{tabular}

"Then with the help of academic experts we identify and evaluate technologies that can address the need, we develop an IP position, potentially combining IP from multiple sources and creating IP ourselves, and put together a company proposal, including the business plan that we will execute on," she added.

Once Enlight identifies a technology platform its pharma partners are interested in, it acquires rights to the IP, develops a business plan and founds a company. Enlight first applied this approach to Endra Inc., which was founded in 2008 to develop a photoacoustic imaging system that can take high-resolution tomography images without researchers needing to inject contrast agents.

"Each pharma partner can decide if and how it will be involved with a new company-participation may be based around a research collaboration or be a strategic partnership, which may include an equity investment," noted Browner.

Alan Lamont, business development director at AstraZeneca, said joining Enlight gives the pharma "the opportunity to leverage investment across a number of pharma partners to generate new collaborations and companies to address these challenges. We are also excited by the opportunity to collaborate with pharma colleagues to access different thinking and solutions to problems."

"Clearly when it comes to platform technologies, cross-pharma validation of applicability may lead to investments which we would otherwise be more reluctant to consider," said Tomas Landh, director of strategy and sourcing at the diabetes research unit of Novo Nordisk. "In the case of Enlight, establishing networks and exploring precompetitive pharma-pharma relations are positive outcomes in and of themselves."

\section{Precompetitive for-profit}

In addition to Endra, Enlight has also founded Entrega Inc., Knode Inc. and Ensōf Biosystems Inc. (See Table 1, "Enlight's offspring.") Browner said pharmas have participated in each company but would not disclose which pharma invested in which startup.

"Because we focus on platform technologies, the magnitude of exits can be smaller than those realized by therapeutic-based companies but the timelines may be shorter. For our portfolio companies we can envision business plans where revenues may be realized in 2-3 years, and the companies can potentially become profitable relatively quickly-and there is usually a longer-term business strategy for continued value creation," said Browner.

She pointed to Endra as an example, saying the company's photoacoustic imaging system has short-term use in pharma preclinical development and long-term potential as a clinical imaging tool. Their preclinical photoacoustic imaging system was commercially launched in 2010 .

Browner said Enlight falls squarely into a precompetitive space 


\section{ANALYSIS}

\section{TRANSLATIONAL NOTES}

that pharma has been increasingly comfortable with. "Something like preclinical imaging technology doesn't need to be owned outright by pharma; it's not their core business. These days the technology toolbox that is needed in pharma is very large; no one can have all the expertise and technology development in-house in every area, so they are looking for ways to access both the technology and expertise without necessarily having to buy it outright, and Enlight provides a means to that goal," she said.

Lamont pointed to the growth of Enlight's portfolio of companies and the scope of technology evaluated by Enlight over the past three years as key reasons AstraZeneca decided the time was ripe to join, adding that the companies and technologies aligned with strategic areas of interest for AstraZeneca.

Landh also told SciBX, "Enlight's reach has clearly been shown to be effective in areas highly relevant for Novo Nordisk."

Going forward, Browner believes "that what is defined as precompetitive will change and expand, and so we are now thinking about novel ways to address the needs in areas of more basic biology and disease understanding. The focus could be on identifying opportunities for drug discovery and development-the pharmas would then compete on how to capitalize on those opportunities."

She declined to be more specific but said many pharmas are investing in basic disease biology through partnerships with academics and that sharing such information could improve efficiency.

Cain, C. SciBX 5(3); doi:10.1038/scibx.2012.60

Published online Jan. 19, 2012

\section{COMPANIES AND INSTITUTIONS MENTIONED}

Abbott Laboratories (NYSE:ABT), Abbott Park, III.

AstraZeneca plc (LSE:AZN; NYSE:AZN), London, U.K.

Eli Lilly and Co. (NYSE:LLY), Indianapolis, Ind.

Endra Inc., Ann Arbor, Mich.

Enlight Biosciences LLC, Boston, Mass.

Ensōf Biosystems Inc., Boston, Mass.

Entrega Inc., Boston, Mass.

Johnson \& Johnson (NYSE:JNJ), New Brunswick, N.J.

Knode Inc., Boston, Mass.

Merck \& Co. Inc. (NYSE:MRK), Whitehouse Station, N.J. Novo Nordisk A/S (CSE:NVO; NYSE:NVO), Bagsvaerd, Denmark

Pfizer Inc. (NYSE:PFE), New York, N.Y.

PureTech Ventures, Boston, Mass. 